\title{
Analysis of the State, Directions and Problems of the Development of the Catering Market of the Region
}

\author{
Aleksey Shipitsyn \\ Combient Mix AB \\ Stockholm, Sweden \\ scienceedu@yandex.ru
}

\begin{abstract}
The article is devoted to the analysis of the dynamics of indicators of the public catering market of the Belgorod region of Russia. The aim of the article is to analyze the directions and problems of development, identify positive and negative factors, prospects for the development of the regional market of public catering in the region. The analysis method was used to study the dynamics of quantitative indicators of the regional catering market based on static data. The sociological method reveals the factors that affect the regional public catering market. SWOT analysis was used to assess the potential of the region's catering market. The development of the public catering market in the region will allow us to achieve the most complete satisfaction of the needs of the population. To ensure the effective development of the industry's infrastructure, it is necessary to create favorable conditions for the growth of business activity. The main problems of development of public catering on the example of the market of the Belgorod region of Russia are revealed. It is established that the low level of use of modern technologies causes a significant lag in the public catering market from other industries. The directions of development of the regional public catering market are suggested.
\end{abstract}

Keywords-regional catering market, the catering market, catering, the development of catering market, the indicators of the catering market, factors market catering.

\section{INTRODUCTION}

Problems of development of public catering in regions of Russia represent special theoretical and practical interest. The catering market is an important element of the regional economy (Kruczala, 1986).

Catering is considered one of the most promising and rapidly developing sectors in the regions (Logachev \& Veretennikov, 2016). The food service market in the regions is changing to reflect people's preferences and values (Astafeva, Nizeev \& Osipova, 2019; Risku-Norja, Løes, 2017). The industry of catering services has a rapidly growing turnover. The increase in demand and supply in the regional markets of public catering has created new market conditions and a competitive environment in the industry, which has received an incentive for further development.

The regional market of public catering is a large organizational and economic system including all organizational forms of food which main task is restoration and maintenance of health of people (Frolov \& Kim, 2015). This explains the high rates of development of enterprises in this sector (Khodykina, Alieva \& Volkova, 2017).

A wide range of needs satisfied by the enterprises of the regional market of public catering, create conditions for entering the market of the most various organizations applying various competitive levers and methods. In the structured market of services in this area there is a constant diversification of market relations in terms of diversity of all components of the marketing strategy.

The catering market in the Belgorod region is an integral part of the consumer sector, whose importance for the economy and the community is very high. The consumer market is a sphere of direct economic impact on a person and a factor of political stability in a society (Moudry, Moudry \& Jelinkova, 2016).

\section{METHODS}

Based on official statistics, an analysis of the key parameters of the region's public catering market was carried out, namely, such indicators: the number of business entities on the market, the number of seats in the catering network per 1,000 people, the turnover of catering, the index of the physical volume of turnover of catering enterprises the share of catering turnover in gross regional product, the turnover of catering per capita, the share of catering expenses in the structure of consumer expenditures s population.

The method of interviewing experts established the values of qualitative indicators of the catering market of the region: the quality of goods and products sold, variety of assortment, price level, service culture, additional services, conditions for the provision of services, the interior of establishments, an individual approach to guests. The sociological method is used to identify positive and negative factors affecting the catering market of the region. The SWOT analysis was used to assess the potential of the catering market of the region.

\section{LITERATURE REVIEW}

The study of the regional market of public catering as a complex system of institutions in the sphere of circulation with a large number of interconnections is devoted to a large number of works.

The researchers found that each of the participants in the 
regional catering market has its own interests: producers seek to return the money spent and make a profit, and consumers seek to satisfy their own needs (Crespi-Vallbona \& Dimitrovski, 2016; Davidovich, 2014). To resolve the contradictions of these interests, state regulation of the economy by the authorities is necessary. (Yakimchuk, Chistnikova, Bondareva \& Dynnikov, 2017).

Unique parameters of development of regional catering systems are formed under the influence of a combination of factors (Elshin, Gayazov \& Prygunova, 2016; Gunawan, Shieh \& Pei, 2015; Zhulina \& Kitsis, 2016).

To analyze the trends in the development of the catering market, a set of indicators has been formed subject to statistical accounting (Kitsis \& Vavilova, 2018). The turnover of public catering, along with the volume of retail trade, is used in most developed countries as an indicator of the expected state of the economy, as a decrease in consumer activity, which inevitably leads to a decrease in the rate of economic growth, most of which quickly affect the dynamics of retail turnover. (Vorotilova \& Gudyma, 2017; Mikhailyuk O. N. \& Zolotarev I. A., 2012).

The main problems in the development of the catering market of the region are:

- insufficient effectiveness of state regulation;

- insufficient level of infrastructure development (lack of retail facilities, high cost of buying and renting real estate and land, high cost of engineering communications, lack of infrastructure in remote or inaccessible settlements, weak economic ties between manufacturers and trade organizations, etc. );

- low qualifications and lack of staff at all levels;

- insufficient attractiveness for the business of developing catering in remote or inaccessible settlements of the region. (Katajevka \& Fokina, 2014; Neganova \& Chirkov, 2014).

The stabilization and development of the catering market depends on transformation through the introduction of innovative products and digital technologies (Stukalo, Dombrovskaya \& Aralova, 2017; Pyanikova, Kovaleva \& Bykovskaya, 2019).

The goals for the development of the catering market in the region in the future should be:

- ensuring the balanced development and deployment of catering infrastructure;

- creating conditions aimed at the development of modern formats of public catering organizations;

- promotion of domestic products, including regional manufacturers, in the consumer market;

- increasing the economic (price) availability of goods and services for the population of the region, creating conditions for ensuring the quality and safety of goods in the regional consumer market;

- stimulating the development of public catering in rural areas, including in remote or inaccessible settlements;

- improving the quality and culture of serving the population of the region;
- information and analytical support in the field of trading. (Mayurnikova, Krapiva, Davydenko \& Samoylenko, 2015; Ugarova, Bolkhovitina \& Davydenko, 2019; Chernov \& Chernova, 2015).

A systematic analysis of the development, implementation and policy instruments for the development of the catering market at the territorial level is needed (Doernberg, Hornet, Zasada \& Piorr, 2018).

The tasks of authorities in the development of public catering in the region are:

- creation of conditions for providing residents of the region with catering services;

- coordination of the development of consumer market infrastructure in the region;

- participation in the implementation of systemic measures to implement, protect and protect the rights of citizens in the field of consumer protection in the region;

- coordination of work on the timely implementation of development strategies of the regional consumer protection system;

- the formation and maintenance of registers of public catering enterprises in the region;

- development of short-term and long-term forecasts of the socio-economic development of the region, analysis and quarterly preparation of materials on the results achieved;

- organization and holding of public catering competitions to improve the quality of services provided by public catering enterprises, and the formation of new standards in the field of public catering;

- carrying out work on awarding regional, departmental awards with honors in the work of the Ministry of Industry and Trade of the Russian Federation to individuals and groups of enterprises, institutions and organizations in the field of public catering;

- carrying out celebrations dedicated to the celebration of professional holidays;

- monitoring the state of the regional consumer market in the area of "Catering", analysis of its development trends (Batabyal \& Beladi, 2016; Cutrini \& Valentini, 2017; Zakharova, Kardava, Avanesova \& Avramenko, 2016).

Authorities can help improve the efficiency of the catering sector by creating an enabling environment (Yakubuk, 2015).

The strategic direction in the Belgorod region is the development of small and medium-sized businesses, including in the public catering sector. Most-favored-nation treatment for business is provided by mechanisms for organizational, financial, credit and property support to small and medium-sized businesses within the framework of the subprogramme for the development of this sector, as stipulated by the current state program "Development of Economic Potential and Creating a Favorable Business Climate for the Belgorod Region for 2014-2020".

It is necessary to implement measures to increase labor productivity (through raising the level of education and "creativity" of workers), as well as the development of a system of priority support for highly qualified specialists in 
the public catering sector. (Kazaryan \& Charyeva, 2016; Manaeva \& Rastvortseva, 2016).

Effective mechanisms for the development of the regional public catering market in the region and the elimination of infrastructure risks are the promotion and implementation of technological and managerial innovations (Pyryakova, E. A. et al., 2019), the implementation of public procurement policies (Cerutti, Ardente, Contu, Donno \& Beccaro, 2017).

At the same time, it is important to assess changes in consumer welfare as a major factor in the transformation of food and public catering markets (Berendeeva, 2019; Soroka \& Wojciechowska-Solis, 2019).

A significant lever influencing the increase in food prices is price monitoring at all stages of commodity circulation: from production to the sale of food in a wholesale and retail network. (Chistnikova, Antonova, Yakimchuk, Glotova \& Dynnikov, 2017).

\section{MAIN PART}

4.1. Characteristics of the market of public catering Belgorod region
The food market is the largest consumer market in the Russian Federation in general and in the Belgorod region in particular.

Dynamics of quantitative indicators of the market of public catering of the Belgorod region in 2014-2018 is presented in Table. 1.

The number of business entities in 2018 decreased by 1 compared to 2014, which indicates stability in the catering network, which significantly affects the satisfaction of consumer requests.

The number of seats has increased, which allows you to place more guests in one restaurant or cafe. On average in 2014-2018 for 1 thousand people there were 35-39 places at the enterprises of the public network with a standard of 40 places. This indicator in the Belgorod region is close to normal.

TABLE I. DYNAMICS OF QUANTITATIVE INDICATORS OF THE MARKET OF PUBLIC CATERING OF THE BELGOROD REGION IN 2014-2018

\begin{tabular}{|c|c|c|c|c|c|c|c|}
\hline Indicators & 2014 & 2015 & 2016 & 2017 & 2018 & $\begin{array}{c}2018 / \\
2014, \\
(+,-)\end{array}$ & $\begin{array}{c}2018 / \\
2014, \\
\% \\
\end{array}$ \\
\hline Number of economic subjects of public catering, units & 2427 & 2415 & 2420 & 2422 & 2426 & -1 & 99,9 \\
\hline Number of seats for all public catering establishments, thousand units & 139.7 & 138.5 & 140.1 & 141.3 & 141.8 & 2,1 & 101.5 \\
\hline $\begin{array}{c}\text { Number of seats in the public catering network for } 1 \text { thousand people, } \\
\text { units }\end{array}$ & 35 & 38 & 39 & 39 & 39 & 4 & 111.4 \\
\hline Turnover of public catering, mln. rubles & 6280.3 & 6811.3 & 7278.6 & 7902.2 & 8428.8 & 2148.5 & 134.2 \\
\hline Index of physical volume of turnover of public catering, $\%$ & 105.3 & 108.6 & 106.9 & 108.6 & 106.7 & 1.4 & 101.3 \\
\hline Share of turnover of public catering in gross regional product, $\%$ & 1.01 & 0.99 & 0.99 & 1.01 & 1.01 & 0 & 100.0 \\
\hline Turnover of public catering per capita, mln. rubles & 4062 & 4397 & 4691 & 5101 & 5448 & 1386 & 134.1 \\
\hline $\begin{array}{l}\text { The share of expenditures on public catering in the structure of } \\
\text { consumer spending of the population, } \%\end{array}$ & 2.2 & 2.3 & 2.0 & 2.2 & 2.2 & 0 & 100.0 \\
\hline
\end{tabular}

Source: belg.gks.ru/

The turnover of public catering in 2018 amounted to 8428.8 million rubles, and in 2014 - 6280.3 million rubles. This indicator compared to 2014 increased by $34.2 \%$, which indicates the growth of production and the effectiveness of sales of catering products.

The index of the physical volume of public catering turnover increased by $1.4 \%$ compared to 2014 , which indicates not only an increase in the volume of public catering, but also an increase in prices for the products of public catering enterprises.

Consider the qualitative indicators of the market of public catering in the Belgorod region in 2013-2017, calculated by the expert method (poll of experts) on a scale of 1 to 10 (where 1 point is the lowest value, 10 points is the highest value of the indicator) (Table 2).

TABLE II. DYNAMICS OF QUALITATIVE INDICATORS OF THE MARKET OF PUBLIC CATERING OF THE BELGOROD REGION IN $2014-2018$ (SCORE ON A SCALE OF 1 TO 10)

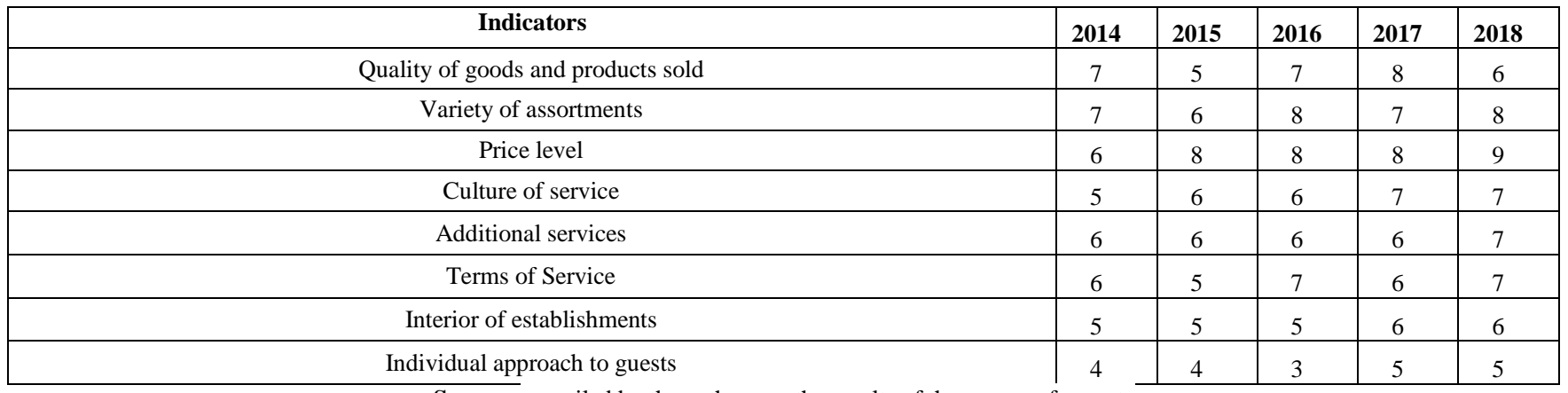

Source: compiled by the authors on the results of the survey of experts 
The public catering market of the Belgorod region is currently quite developed in terms of the quality of goods, the level of prices and the culture of service.

In 2014-2018 years. The individual approach to guests was improved and the culture of customer service was improved, which indicates an increased competition in the catering market.

Ethics and the ability to communicate with visitors increase the reputation of institutions, which has an impact on attendance.

Also in 2017-2018, much attention was paid to the interior of the establishments, as the goals of the clients changed, they want not only to eat deliciously or hold a celebration, but also to have a good time. The price level has increased by 3 units in comparison with 2014, the reasons for this are inflation, as well as the rise in price of agricultural products.
4.2. The analysis of directions and problems of development of the market of public catering of the Belgorod region

The public catering market in the Belgorod region is an open system that responds to both internal and external economic, social and political situations, depends on interregional trade flows, migration of labor, movement of money and capital.

To study the potential for the development of public catering enterprises in the Belgorod region, we used the SWOT-analysis method, which allows us to identify strengths and weaknesses, as well as opportunities and threats against competitors.

SWOT-analysis of the potential of the market of public catering of the Belgorod region is presented in Table 4.

TABLE III. SWOT-ANALYSIS OF THE POTENTIAL OF THE CATERING MARKET IN THE BELGOROD REGION

\begin{tabular}{|c|c|}
\hline Strengths & Weakness \\
\hline $\begin{array}{c}\text { - variety of public catering infrastructure in Belgorod } \\
\text { - public catering establishments, aimed at different segments of consumers } \\
\text {-a sufficiently high level of service at public catering establishments in the } \\
\text { city of Belgorod } \\
\text { - availability of qualified personnel in the labor market of the Belgorod } \\
\text { region } \\
\text { - the availability of innovative technologies and the possibility of their } \\
\text { implementation } \\
\text { - established relationships with suppliers of products }\end{array}$ & $\begin{array}{c}\text { - weak motivation of local population in entrepreneurship } \\
\text { - Inadequate number of public catering establishments in district centers } \\
\text { - insufficiently high level of service in public catering establishments in } \\
\text { district centers } \\
\text { - lack of clear strategic directions } \\
\text { - obsolete equipment at operating food enterprises } \\
\text { - lack of experience in marketing research } \\
\text { - insufficient use of marketing tools } \\
\text { - unstable sales volumes }\end{array}$ \\
\hline Opportunities & Threats \\
\hline $\begin{array}{c}\text { - realization of an active investment policy in the sphere of catering of the } \\
\text { region } \\
\text { - ensuring sustainable development of catering, improving quality and } \\
\text { expanding the range of services } \\
\text { - application of modern information technologies } \\
\text { - use of modern automation systems } \\
\text { - an increase in the number of local producers of raw materials } \\
\text { - attraction of highly qualified management personnel }\end{array}$ & $\begin{array}{c}\text { - economic and political destabilization } \\
\text { - change in tastes and preferences of the population } \\
\text { - Fierce competition through the entry of large international enterprises } \\
\text { - increase in prices for raw materials }\end{array}$ \\
\hline
\end{tabular}

The low level of use of modern technologies causes a significant lag in the catering market of the Belgorod Region from the catering sector of developed countries in terms of efficiency level 5 and more times.

In order to solve these problems in the Belgorod region, it is necessary: the formation of a new regulatory framework in the sphere of consumer market regulation, the development of a strategy and program for the development of public catering, and the development of law enforcement mechanisms.

\subsection{Perspective of development of the regional market of} public catering
Having analyzed the state of the regional market of public catering in the Belgorod region, it can be concluded that the obstacle to its development is in the field of regulatory policy. The area of nutrition in public places in the Belgorod region is not sufficiently developed: the share of out-of-home expenses in the total costs of the population for food was no more than $3 \%$.

Currently, a large number of events are being held that implement the necessary directions for the development of the regional catering market.

The plan for implementing measures for the development of the market of public catering in the Belgorod region is presented in Table. 5 .

TABLE IV. MEASURES FOR THE DEVELOPMENT OF THE MARKET OF PUBLIC CATERING IN THE BELGOROD REGION

\begin{tabular}{|c|c|}
\hline \multicolumn{1}{|c|}{ Events } & Directions \\
\hline $\begin{array}{c}\text { 1. Development of the Strategy for the Development of Public } \\
\text { Catering in the Territory of the Belgorod Region for 2018-2025. } \\
\text { 2. Development and implementation of activities for the } \\
\text { implementation of the Strategy for the Development of Public } \\
\text { Catering in the Territory of the Belgorod Region for 2018-2025. }\end{array}$ & $\begin{array}{c}\text { - increase in the turnover of public catering; } \\
\text { - creation of conditions for increasing the number of economic entities } \\
\text { engaged in public catering; }\end{array}$ \\
\hline $\begin{array}{c}\text { Organization and holding competitions of professional skills, } \\
\text { festivals, master classes - at least 4 annually }\end{array}$ & $\begin{array}{c}\text { Increase of professional skill and professional skill of the personnel at public } \\
\text { catering establishments, and also at the enterprises rendering household } \\
\text { services to the population }\end{array}$ \\
\hline $\begin{array}{c}\text { Conducting competitions of professional skills, festivals, master } \\
\text { classes, including among students of educational organizations }\end{array}$ & Promoting the profession of the service industry \\
\hline
\end{tabular}




\begin{tabular}{|c|c|}
\hline Events & Directions \\
\hline The international barbecue festival "Grill Fest" & $\begin{array}{c}\text { - increase in the turnover of public catering; } \\
\text { - popularization of the profession of public catering services; } \\
\text { - creation of conditions for investment attractiveness of local commodity } \\
\text { producers; } \\
\text { - promotion of the products of local commodity producers to the domestic and } \\
\text { foreign markets. }\end{array}$ \\
\hline $\begin{array}{c}\text { Keeping a register of public catering establishments and household } \\
\text { services and conducting an analysis of the situation in the services } \\
\text { market }\end{array}$ & $\begin{array}{c}\text { Study of the situation on the state of the competitive environment in the } \\
\text { sphere of public services and catering services in the region }\end{array}$ \\
\hline
\end{tabular}

Source: compiled by the authors.

For the analysis of methods for stimulating the sale of products of public catering enterprises in the Belgorod region, we will examine the main areas:

$$
\begin{aligned}
& \circ \quad \text { intra-firm incentives; } \\
& \circ \quad \text { stimulation of consumers. }
\end{aligned}
$$

\section{CONCLUSION}

The market of public catering of the Belgorod region is an important structural element of the social infrastructure of the region, the role of public catering is quite significant and is aimed at fulfilling the main function - the creation of a set of conditions for the development of the economy of the region and ensuring normal human life. Besides, the market of public catering of the Belgorod region carries out important economic and social functions, maintaining a high standard of living of the population, providing employment, development of small business and economic development of area. That causes need of further research of the analysis of the directions and problems of development of the market of public catering of the Belgorod region.

Consumers began to either go to places of public catering or to refuse expensive dishes. There is also a trend of outflow of visitors from expensive restaurants in the middle segment and fast food. A significant influence on this trend was made by the rise in price of prices - the dollar and euro rates increased, therefore, products are purchased at higher prices, rental costs also increased, utility payments increased, fees for security measures increased. Thus, the costs of enterprises have increased, and this is all pawned in the price.

To ensure the effective development of the industry's infrastructure, it is necessary to create favorable conditions for the growth of entrepreneurial activity, maintain competition and the balanced development of various types and methods of food trade.

\section{REFERENCES}

[1] O.V. Astafeva, A.D. Nizeev, and I.A. Osipova, "Developing of bicycle cafes on the analysis of trends in healthy lifestyle", European Proceedings of Social and Behavioural Sciences EpSBS, 2019, pp. 185-192. DOI: https://www.doi.org/10.15405/epsbs.2020.03.26

[2] A.A. Batabyal, and H. Beladi, "Trade between creative regions when the input elasticity of substitution is less than unity", Regional Science Inquiry, 2016, no 8(3), pp. 11-18.

[3] E.V. Berendeeva, "Transformation of the Russian food market: effects of income and substitution", HSE economic journal, 2019, no 23 (4), pp. 605-623. DOI: https://www.doi.org/10.17323/1813-8691-2019-234-605-623

[4] N.I. Borovskikh, "Regional public catering market: analysis and development prospects", Omsk scientific herald, 2017, no 2, pp. 71-75.

[5] N.V. Borovskikh, "Methods and tools of non-price competition in the public catering market", Omsk scientific Vestnik. Ser. Society. History. Modernity, 2018, no 1, pp. 96-100. DOI: https://www.doi.org/10.25206/2542-0488-2018-1-96-100
[6] A.K. Cerutti, F. Ardente, S. Contu, D. Donno, and G.L. Beccaro, "Modelling, assessing, and ranking public procurement options for a climate-friendly catering service", The International Journal of Life Cycle Assessment, no 23, pp. 95-115. DOI: https://www.doi.org/10.1007/s11367-017-1306-y

[7] G.E. Chernov, and E.V. Chernova, "Public Catering in Russia: New Chalengies of Chaning Russia", On the Way to a Stable World: Security and Sustainable Development. A Collection of Scientific Papers. San Diego, 2015, pp. 93-97. DOI:https://www.doi.org/10.17809/02(2015)-GP

[8] I.V. Chistnikova, M.V. Antonova, S.V. Yakimchuk, A.S. Glotova, and Y.A. Dynnikov, "Indicators and a mechanism to ensure economic security of the regions", Regional Science Inquiry, 2017, no 9 (1), pp. $97-105$.

[9] M. Crespi-Vallbona, and D. Dimitrovski, "Food markets visitors: a typology proposal", British Food Journal, 2016, no 118 (4), pp. 840857. DOI: https://doi.org/10.1108/BFJ-11-2015-0420

[10] E. Cutrini, and E. Valentini, "Regional strategies for dealing with structural change", Regional Science Inquiry, 2017, no 9(1), pp. 107117.

[11] A.R. Davidovich, "Catering establishments as a basis for tourist space formation in Sochi", Contemporary issues of service and tourism, 2014, no 8, pp. 60-68. DOI: https://doi.org/10.12737/4311

[12] A. Doernberg, P. Horn, I. Zasada, and A. Piorr, "Urban food policies in German city regions: An overview of key players and policy instruments", Food Policy, 2018, no 89, pp. 101782.DOI: https://doi.org/10.1016/j.foodpol.2019.101782

[13] L.A. Elshin, Z.F. Gayazov, and M.I. Prygunova, "Methodological approaches to scenario forecasting of the development of the public catering system in the regions of Russia", Theoretical and applied Economics, 2016, no 4, pp. 121-131.DOI: https://www.doi.org/10.7256/2409-8647.2016.4.19913

[14] D.P. Frolov, and I.D. Kim, "Marketing Analysis of Public Catering Market in Russia: District, Regional, and Segment Aspects", Economic development management, 2015, no 3 (32), pp. 38-51.DOI: http://dx.doi.org/10.15688/jvolsu3.2015.3.4

[15] S. Gunawan, C.-J. Shieh, and Y. Pei, "Effects of crisis communication strategies and media report on corporate image in Catering Industry", Acta Oeconomica, 2015, no 65, pp. 399-411.DOI: https://www.doi.org/10.1556/032.65.2015.S2.29

[16] N.N. Katajevka, and O.V. Fokina, "Laws of development of the Russian and regional market of public catering", Economics and entrepreneurship, 2014, no 11-4, pp. 404-409.

[17] M.A. Kazaryan, and M.O. Charyeva, "Features of regional development of the market of public catering in Russia", Economics, 2016, no 144, pp. 36-41.

[18] M. Khodykina, F. Alieva, and T. Volkova, "The branch of public catering in Krasnodar region: main indicators and forecasts of development", Services and Russia and abroad, 2017, no 11 (3), pp. 111-125. DOI: https://www.doi.org/10.22412/1995-042X-11-3-10

[19] V.M. Kitsis, and A.V. Vavilova, "Level of the Development and Distribution of Public Catering Enterprises in Rural Areas of the Republic of Mordovia”, Regionology, 2018, no 26 (3), pp. 578-605. DOI: https://doi.org/10.15507/2413-1407.104.026.201803.578-605

[20] J. Kruczala, "The role of catering facilities in the local and regional tourist facilities complexes", The Tourist Review, 1986, no 41 (4), pp. 16-17.DOI: https://doi.org/10.1108/eb057957

[21] K.I. Logachev, and A.I. Veretennikov, "Improvement of industrial and territorial small business structures in the Russian economy", Scientific result. Economic research, 2016, no 2 (4), pp. 21-27. DOI: https://www.doi.org/10.18413/2409-1634-2016-2-4-21-27

[22] I. Manaeva, and S. Rastvortseva, "Zipf's law as assessment tool of urban inequality", Regional Science Inquiry, 2016, no 8(3), pp. 19-30. 
[23] L.A. Mayurnikova, T.V. Krapiva, N.I. Davydenko, and K.V. Samoylenko, "Analysis and prospects of catering market in regions", Food Processing: Techniques and Technology, 2015, no 1, pp. 147151.

[24] O.N. Mikhailyuk, and I.A. Zolotarev, "Regional market of public catering: features, forms and factors of development", AIC: regions of Russia, 2012, no 7, pp. 41-46. DOI: https://doi.org/10.15507/24131407.104.026.201803.578-605

[25] J.Jr. Moudry, J. Moudry, and Z. Jelinkova, "The Use of Organic Foods, Regional, Seasonal and Fresh Food in Public Caterings", In book: Organic Farming - A Promising Way of Food Production, 2016. DOI:https://www.doi.org/10.5772/61352

[26] V.P. Neganova, and A.V. Chirkov, "Condition and tendencies of a public catering market development", Economy of Region, 2014, no 1, pp. 132-146. DOI: https://doi.org/10.5829/idosi.wasj.2013.22.05.2984

[27] E.A. Pyanikova, A.E. Kovaleva, and E.I. Bykovskaya, "Digital technologies in public catering Industry (regional aspect)", 1st International Scientific Conference "Modern Management Trends and the Digital Economy: from Regional Development to Global Economic Growth" (MTDE 2019), 2019, no 81, pp. 482-488.DOI: https://doi.org/10.2991/mtde-19.2019.96

[28] H. Risku-Norja, and A.-K. Løes "Organic food in food policy and in public catering: lessons learned from Finland. Organic Agriculture", 2017, no 7(2), pp. 111-124. DOI: https://www.doi.org/10.1007/s13165-016-0148-4

[29] A. Soroka, and J. Wojciechowska-Solis, "Consumer Awareness of the Regional Food Market: The Case of Eastern European Border Regions", Foods, 2019, no 8, pp. 467. DOI: https://www.doi.org/10.3390/foods8100467

[30] O.G. Stukalo, Yu.P. Dombrovskaya, and S.I. Aralova, "Improving the competitiveness of catering enterprises through innovative food", Proceedings of the Voronezh State University of Engineering Technologies, 2017, no 79 (4), pp. 306-312. DOI: https://doi.org/10.20914/2310-1202-2017-4-306-312

[31] I. Ugarova, E.N. Bolkhovitina, and N.I. Davydenko, "The development of the regional catering market: The case of the Altai region", International Conference on Sustainable Development of Cross-Border Regions: Economic, Social and Security Challenges (ICSDCBR 2019), 2019, pp. 1397-1402. DOI: https://doi.org/10.2991/icsdcbr-19.2019.35

[32] O.A. Vorotilova, and A.V. Gudyma, "Analysis and prospects of development of the market catering to regional conditions", Management. Business. Authority, 2017, no 5 (14), pp. 68-71.

[33] S.V. Yakimchuk, I.V. Chistnikova, Ya.Yu. Bondareva, and Y.A. Dynnikov, "The Role of Construction Industry Factor in the Economic Development of Regions", International Journal of Economic Perspectives, 2017, no 11 (3), pp. 87.

[34] Yu.P. Yakubuk, "The problems of formation and state regulation of prices in public catering enterprises: the international practice and experience of Belarus", Scientific result. Economic research, 2015, no 1, pp. 24-30. DOI: https://www.doi.org/10.18413 /2409-1634-2015-11-24-30

[35] E.N. Zakharova, E.E. Kardava, R.R. Avanesova, and E.P. Avramenko, "Management of the economic capacity of the region on the basis of foresight (on the example of Adygea, Russia)", Regional Science Inquiry, 2016, no 8(2), pp. 45-54.

[36] M.A. Zhulina, and V.M. Kitsis, "Local tourism clusters in the Republic of Mordovia: the establishment and functioning", Sovremennye problemy servisa i turizma $=$ Service and Tourism: Current Challenges, 2016, no 10(1), pp. 65-72. DOI: https://www.doi.org/10.12737/17786 